Research Article

\title{
Antidiarrheal Activity of Hydromethanolic Root Extract and Solvent Fractions of Clutia abyssinica Jaub. \& Spach. (Euphorbiaceae) in Mice
}

\author{
Dessie Zayede, ${ }^{1}$ Tafere Mulaw, ${ }^{2}$ and Wubayehu Kahaliw iD $^{2}$ \\ ${ }^{1}$ University of Gondar, P. O. Box: 196, Gondar, Ethiopia \\ ${ }^{2}$ Department of Pharmacology, School of Pharmacy, College of Medicine and Health Sciences, University of Gondar, \\ P. O. Box: 196, Gondar, Ethiopia
}

Correspondence should be addressed to Wubayehu Kahaliw; kahaliw_w@yahoo.com

Received 10 September 2019; Revised 28 November 2019; Accepted 14 December 2019; Published 17 January 2020

Academic Editor: Armando Zarrelli

Copyright (C) 2020 Dessie Zayede et al. This is an open access article distributed under the Creative Commons Attribution License, which permits unrestricted use, distribution, and reproduction in any medium, provided the original work is properly cited.

Introduction. Diarrheal diseases are associated with an estimated 1.3 million deaths annually, with most occurring in resourcelimited countries; up to $25 \%$ of deaths in young children living in Africa and southeast Asia are attributable to acute gastroenteritis. Due to limitations associated with various treatments available, the need for developing newer drugs is imperative. Objective. This study was aimed to evaluate the antidiarrheal activity of root extract and fractions of C. abyssinica Jaub. \& Spach. (Euphorbiaceae) in mice. Methods. After plant extraction and subsequent fractionation of the crude extract, the antidiarrheal activity was screened in castor oil induced diarrhea, castor oil induced enteropooling, and gastrointestinal motility test models accordingly. Result. The root extract of $C$. abyssinica produced neither visible signs of toxicity nor death at a single dose of $2000 \mathrm{mg} / \mathrm{kg}$, suggesting the $\mathrm{LD}_{50}>2000 \mathrm{mg} / \mathrm{kg}$. In the castor oil induced diarrheal model, the highest dose of the extract (400 mg/ $\mathrm{kg}$ ) showed a maximal inhibition in the onset $(158.00 \pm 14.64, p<0.01$, in minutes) of wet feces as compared to the negative control. In the enteropooling model, $400 \mathrm{mg} / \mathrm{kg}$ treated mice showed a significant reduction in volume $(0.47 \pm 0.02 \mathrm{ml}, p<0.01)$ and weight $(0.50 \pm 0.02 \mathrm{~g}, p<0.05)$ of intestinal content as compared to the vehicle treated group. In the gastrointestinal motility test, the hydromethanolic root extract of C. abyssinica significantly inhibited the intestinal transit of charcoal meal at $400 \mathrm{mg} / \mathrm{kg}$. In addition, chloroform and $n$-butanol fractions significantly reduced the distance moved by charcoal at doses of $200 \mathrm{mg} / \mathrm{kg}$ and $400 \mathrm{mg} / \mathrm{kg}$, whereas aqueous fraction showed a significant effect at all test doses. The highest antidiarrheal index was observed at the maximal dose of extract and each fraction. Conclusion. The results obtained showed that the findings provide scientific support for the folkloric repute of $C$. abyssinica roots as treatment of diarrhea.

\section{Introduction}

Diarrhea is a symptom of disease marked by rapid and frequent passage of semisolid or liquid fecal materials through the gastrointestinal tract (GIT) along with increased motility and secretions of GIT and decreased fluid absorption [1]. Diarrheal diseases are associated with an estimated 1.3 million deaths annually, with most occurring in resource-limited countries; up to $25 \%$ of deaths in young children living in Africa and southeast Asia are attributable to acute gastroenteritis [2,3]. In Ethiopia, diarrheal diseases are major contributors to under-five mortality. According to the 2018 Ethiopian Demographic and Health Survey report, $12 \%$ of under-five children had a diarrheal episode in the 2 weeks before the survey [4].

Almost $80 \%$ of people in the developing world including Ethiopia use the services of traditional healers as a source of affordable and accessible health care [5]. In addition, currently available drugs are linked with adverse effects, contraindications, and resistance. The high incidence of diarrhea in developing countries coupled with the limitations of conventional antidiarrheal drugs and poor healthcare coverage may make traditional medicines good alternatives for the management of diarrhea [6]. 
Traditional healers have been using numerous medicinal plants for the management of diarrheal diseases. Some of the medicinal plants are Zehneria scabra (Linn. f.) (Cucurbitaceae) [7], Croton macrostachyus Hochst. ex Delile (Euphorbiaceae) [7-9], Lepidium sativum L. (Brassicaceae), Rumex nervosus Vahl. (Polygonaceae), and Verbascum sinaiticum Benth (Scrophulariaceae) [7]. In addition, $C$. abyssinica is one of the medicinal plants being used in traditional medicine. The other species in the genus Clutia are also believed to possess activity against diarrhea according to different ethnobotanical studies in different populations. Among these, Clutia pulchella [10], Clutia lanceolata [11], and Clutia hirsute are medicinal plants possessing antidiarrheal activity. Plant extracts can have antispasmodic effects, delay gastrointestinal transit, suppress gut motility, and stimulate water adsorption [12]. These activities may explain the benefits of using particular plants in the treatment of diarrheal disease.

Clutia abyssinica Jaub. \& Spach (Figure 1), "Fiyele-Feji," (Amharic) belongs to Euphorbiaceae family [13-15]. C. abysinica is distributed from Congo east to Eritrea and Somalia and through eastern Africa, south to Zambia, Angola, Mozambique, and South Africa [16]. C. abyssinica is a medicinal plant which has been used in the management of diarrhea in the central part of Ethiopia, that is, Fiche and Ankober districts [14, 17, 18] without scientific proof for safety and efficacy. Thus, investigating the safety and efficacy of this plant in the animal model could give valuable information in this regard. The findings of this research can be used as an input in searching for a new antidiarrheal agent that might solve problems associated with conventional drugs.

\section{Materials and Methods}

2.1. Drugs and Chemicals. The drugs, chemicals, and reagents used in this study were of the required standard and analytical grade. They were purchased from local suppliers. These include distilled water (Ethiopian Pharmaceutical Manufacturing Factory, Ethiopia), loperamide HCl (Brawn Laboratories Ltd, India), castor oil (Amman Pharmaceutical Industries, Jordan), methanol (Blulux laboratories Ltd, India), activated charcoal (Acuro Organics Ltd, New Delhi), atropine sulphate injection (Reyoung Pharm), chloroform (Finkem Laboratory Reagent, India), and n-butanol (Blulux Laboratories Ltd, India).

2.2. Instruments and Apparatus. Hot air oven (MeditMedizin Technik, Germany), vacuum freeze dryer (Labfreez Instruments Group, Ltd, Germany), digital electronic balance (EPH-400 Abron Exports), and rotary evaporator (Yamato Scientific CO. Ltd, Japan) were used in this study.

2.3. Plant Material. Fresh roots of C. abyssinica were collected from Libo Kemkem district, South Gondar Zone, Amhara region, northwest of Addis Ababa on the $16^{\text {th }}$ of November 2018. The plant was authenticated by a Botanist
(Mr. Abiyu Eniyew Molla) in the Department of Biology, College of Natural and Computational Sciences, the University of Gondar where a specimen was deposited for future reference with voucher number 001DZG.

2.4. Extraction and Fractionation. Fresh roots of C. abyssinica were thoroughly washed under running water to remove dirt and soil and air-dried under shade at room temperature. Then, the dried roots were cut into smaller pieces and milled into fine powder by using an electrical mill. Cold maceration technique was used to extract the plant material. The root powder $(850 \mathrm{~g})$ was macerated with 3 liters of $80 \%$ methanol for three days in an Erlenmeyer conical flask with occasional stirring. The extract was first filtered using a muslin cloth and then with Whatman No. 1 filter paper. The marc was remacerated twice in the same manner to maximize the yield. The filtrates were combined and concentrated in a rotary evaporator under reduced pressure at $40^{\circ} \mathrm{C}$. The concentrated filtrate was frozen overnight in a deep freezer $\left(-20^{\circ} \mathrm{C}\right)$ followed by drying with a lyophilizer at $-50^{\circ} \mathrm{C}$ and vacuum pressure $(200 \mathrm{mBar})$ to remove water. The dried extract was stored in an air tight container in a deep freezer until used.

The hydromethanolic extract $(60 \mathrm{gm})$ was subjected to successive fractionation using solvents of differing polarity (chloroform, $n$-butanol, and distilled water). The crude extract was suspended in $300 \mathrm{ml}$ of distilled water in a separatory funnel and then an equal volume of chloroform was added. The mixture was allowed to form a distinct layer, and the chloroform fraction was separated. This was repeated three times. Then, the aqueous residue was similarly mixed with an equal volume of $n$-butanol and separated. The chloroform and $n$-butanol fractions were concentrated by rotary evaporator and dried by dry oven at $40^{\circ} \mathrm{C}$. The aqueous fraction was dried in a lyophilizer. Finally, chloroform, aqueous, and $n$-butanol fractions were stored in an air tight container in a deep freezer until used.

2.5. Acute Oral Toxicity. The crude extract was evaluated for its toxicity using young female and nonpregnant Swiss albino mice (18-30 g and 6-8 weeks age) based on OECD guidelines 2008:425 [19]. Mice were acclimatized to laboratory conditions for one week prior to the experiment. Food was withheld for 3 hours with a normal supply of water. The fasted body weight of each animal was determined, and the doses were calculated according to the body weight. The crude extract was administered at $2000 \mathrm{mg} / \mathrm{kg}$ by the oral route, and food was withheld for 2 hours after administration. Animals were observed continuously for physical, neurological, autonomic, or behavioural changes during the first 30 minutes and observed periodically (with special attention given during the first 4 hours) for the next 24 hours and then daily thereafter for 14 days. Following the results from the first mouse, the other two mice were recruited and fasted for 3 hours and a single dose of $2000 \mathrm{mg} / \mathrm{kg}$ was administered. Mice were observed in the same manner as the first mouse for any signs of overt toxicity. 


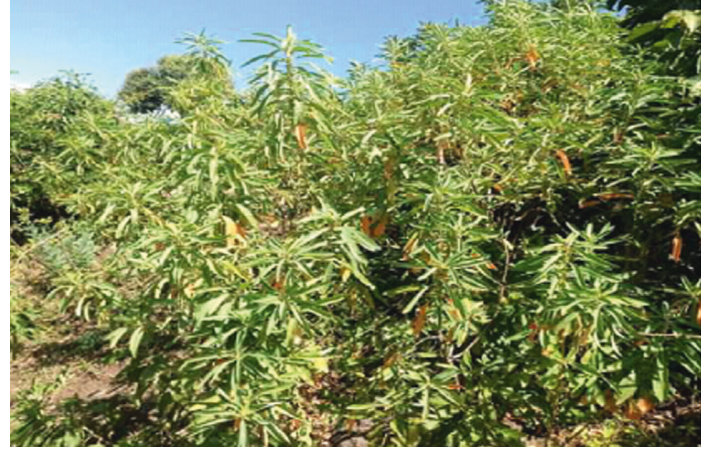

(a)

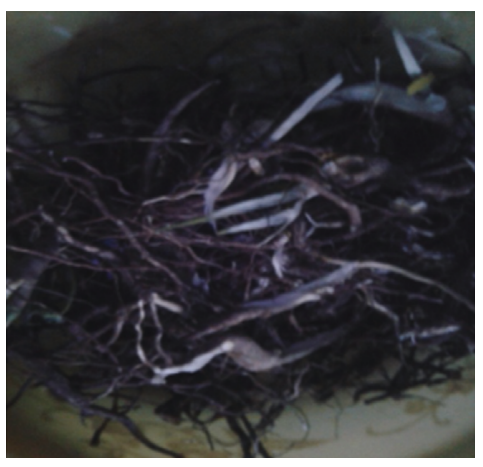

(b)

Figure 1: C. abyssinica Jaub. \& Spach (a) and its roots (b) from the site of collection (captured on 16/11/2018).

2.6. Experimental Animals Handling, Grouping, and Dosing. Swiss albino mice of both sexes (18-30 g and 6-8 weeks of age) were obtained from the Animal House of the Department of Pharmacology, University of Gondar. For each of the three antidiarrheal activity test models, 30 mice were used according to Vogel [20]. The animals were housed in cages under standard conditions in a room with a 12-hour light and dark cycle. They were provided with standard pellet diet and water ad libitum. They were acclimatized to the laboratory condition for a week prior to the experiment. Animals were handled according to international laboratory animal use and care guidelines throughout the experiment [21].

To evaluate the activities of the crude extract and solvent fractions, mice were grouped into five groups of six mice in each three antidiarrheal activity test models. In the three antidiarrheal activity test models, negative control groups (group 1) were treated with vehicle (distilled water for hydromethanolic extract and aqueous fraction and $2 \%$ tweens- 80 for chloroform and $n$-butanol fractions) at $10 \mathrm{ml} /$ $\mathrm{kg}$. Positive control groups (group 2) were treated with loperamide $(3 \mathrm{mg} / \mathrm{kg}$ ) (in castor oil induced diarrhea and gastrointestinal motility models) and atropine $(1 \mathrm{mg} / \mathrm{kg}$ ) (in enteropooling model). Groups 3, 4, and 5 were treated with
$100 \mathrm{mg} / \mathrm{kg}, 200 \mathrm{mg} / \mathrm{kg}$, and $400 \mathrm{mg} / \mathrm{kg}$ of the crude extract and solvent fractions, respectively, in each test model.

\subsection{Antidiarrheal Activity Determination}

2.7.1. Castor Oil Induced Diarrhea. We followed the method of Sisay et al. [22] to evaluate the antidiarrheal activity of extract and fractions in the study. Following grouping and dosing, each animal was fasted for 18 hours and was placed in an individual cage, the floor of which is lined with white paper and replaced every hour. Diarrhea was induced by administering $0.5 \mathrm{ml}$ of castor oil orally to each mouse. Each animal received either vehicle or treatment one hour before castor oil according to the respective grouping as described above. Onsets of diarrhea, frequency of defecation, and weight of wet and total stools were recorded for each animal for a total of 4 hours. The onset of diarrhea was measured as the time interval in minutes between the administration of castor oil and the appearance of the first diarrheal stool. The total number of diarrheal feces of the control group was considered $100 \%$. Percent inhibition (PI) was calculated as follows [23]:

$$
\mathrm{PI}=\frac{\text { mean number of wet stools }(\text { negative control group }- \text { treated group }) \times 100}{\text { mean number of wet stools of the negative control group }}
$$

2.7.2. Castor Oil Induced Enteropooling. The effects of the plant extract on intraluminal fluid accumulation were determined using the method described by Robert et al. [24]. Animals were fasted for 18 hours, grouped, and treated as described above. One hour after treatment, $0.5 \mathrm{ml}$ castor oil was administered. Animals were sacrificed by cervical dislocation one hour after castor oil administration. The abdomen of each animal was then opened; the small intestine was ligated at both the pyloric sphincter and the ileocecal junction and dissected. The dissected small intestine was weighed and intestinal contents were collected by milking into a graduated tube and volume of the contents was measured. The weight of the intestine after milking was taken, and the difference between the two weights recorded. Finally, the percentage reduction of intestinal secretion (volume and weight) was calculated relative to the negative control using the following formula:

$\%$ of inhibition by using MVIC $=\frac{\text { MVICC }- \text { MVICT }}{\text { MVICC }} \times 100$,

where MVIC is the mean volume of intestinal content, MVICC is the mean volume of intestinal content of the control group, and MVICT is the mean volume of intestinal content of the test group. 
$\%$ of inhibition by using MWIC $=\frac{\text { MWICC }- \text { MWICT }}{\text { MWICC }} \times 100$,

where MWIC is the mean weight of intestinal content, MWICC is the mean weight of intestinal content of the control group, and MWICT is the mean weight of intestinal content of the test group.

2.7.3. Gastrointestinal Motility Test. Animals were fasted for 18 hours with free access to water and treated according to their respective grouping 30 minutes before the administration of castor oil [25]. Half $\mathrm{ml}$ of marker activated charcoal was administered orally 30 minutes after castor oil treatment.

The animals were sacrificed after 30 minutes of charcoal administration and then small intestine (from the pylorus to the cecum) was rapidly removed and laid out on white paper. The tissue was then inspected, and the distance traversed by the charcoal meal was measured. This distance was calculated as a percentage of the whole intestine length using the following relation [26]:

$$
\begin{gathered}
\text { peristalsis index }(\mathrm{PI})=\frac{\text { distance traveled by the charcoal marker }}{\text { total length of small intestine }} \times 100, \\
\% \text { of inhibition }=\frac{\text { PI of negative control }- \text { PI of treated group }}{\text { PI of negative control }} \times 100 .
\end{gathered}
$$

The in vivo antidiarrheal index (ADI) was then calculated according to the formula shown below [26]:

$$
\text { in vivo antidiarrheal index }(\mathrm{ADI})=\sqrt[3]{\mathrm{Dfreq} \times \mathrm{Gmeq} \times \mathrm{Pfreq}} \text {, }
$$

where Dfreq is the delay in defecation time or diarrheal onset (in \% of control), Gmeq is the gut travel reduction (in \% of control), and Pfreq is the purging frequency as number of stool reduction (in \% of control).

2.8. Ethical Clearance. The study protocol was approved by the Institutional Ethical Review Board of University of Gondar. Animals were handled according to international laboratory animal use and care guidelines throughout the experiment.

2.9. Statistical Analysis. Results were expressed as the mean \pm standard error of the mean (SEM) of responses. All the results were analyzed statistically using SPSS Software Ver. 24, and the statistical significance was determined using the one-way analysis of variance (ANOVA) followed by Tukey's post hoc test. A $p$ value less than 0.05 was considered to be significant.

\section{Results}

3.1. Acute Oral Toxicity Test. The hydromethanolic root extract of $C$. abyssinica produced neither visible signs of toxicity during the 14-day observation period nor death within 24 hours following oral administration of a single dose of $2000 \mathrm{mg} / \mathrm{kg}$. In addition, no toxic symptoms were observed and they did not show any reduction in food and water intake during the period of 14 days. The absence of mortality and visible signs of toxicity up to 5 times the maximum dose of the extract suggested that the hydromethanolic extract has a wider safety margin and the median lethal dose $\left(\mathrm{LD}_{50}\right)$ could be greater than $2000 \mathrm{mg} / \mathrm{kg}$.

3.2. Castor Oil Induced Diarrhea. In the castor oil induced diarrheal model, the hydromethanolic root extract of C. abyssinica significantly prolonged the onset of diarrhea and reduced the number of wet and total stools at doses of $200 \mathrm{mg} / \mathrm{kg}$ and $400 \mathrm{mg} / \mathrm{kg}$ as compared to the negative control. In addition, the percentage reductions of wet stools were $32.32 \%, 53.83 \%$, and $67.68 \%$ at the doses of $100 \mathrm{mg} / \mathrm{kg}$, $200 \mathrm{mg} / \mathrm{kg}$, and $400 \mathrm{mg} / \mathrm{kg}$, respectively (Table 1 ).

Chloroform fraction significantly prolonged the onset of diarrhea $(p<0.001)$ and reduced the number of wet $(p<0.001)$ and total $(p<0.001)$ stools at the maximum dose $(400 \mathrm{mg} / \mathrm{kg})$ as compared to the negative control. However, $200 \mathrm{mg} / \mathrm{kg}$ chloroform fraction showed a significant effect only on the reduction of the number of wet $(p<0.05)$ and total $(p<0.05)$ feces. The percentage reductions of wet feces induced by chloroform fraction were $27.70 \%, 39.98 \%$, and $63.07 \%$ at doses of $100 \mathrm{mg} / \mathrm{kg}, 200 \mathrm{mg} / \mathrm{kg}$, and $400 \mathrm{mg} / \mathrm{kg}$, respectively. The $n$-butanol fraction significantly reduced fecal output at doses of $200 \mathrm{mg} / \mathrm{kg}$ and $400 \mathrm{mg} / \mathrm{kg}$ as compared to the negative control. This fraction also showed percentage reductions in wet feces of $33.80 \%, 41.55 \%$, and $61.5 \%$ at doses of $100 \mathrm{mg} / \mathrm{kg}, 200 \mathrm{mg} / \mathrm{kg}$, and $400 \mathrm{mg} / \mathrm{kg}$, respectively. Aqueous fraction reduced fecal output significantly at all test doses with the percentage reductions of wet feces, $47.65 \%, 58.45 \%$, and $66.11 \%$, at doses of $100 \mathrm{mg} / \mathrm{kg}$, $200 \mathrm{mg} / \mathrm{kg}$, and $400 \mathrm{mg} / \mathrm{kg}$, respectively. Aqueous and $n$ butanol fractions were devoid of any significant delay in the onset of diarrhea at all test doses (Table 1).

3.3. Castor Oil Induced Enteropooling. The hydromethanolic root extract of $C$. abyssinica failed to confer a statistically significant reduction in both the average volume and weight of intestinal contents at both $100 \mathrm{mg} / \mathrm{kg}$ and $200 \mathrm{mg} / \mathrm{kg}$ doses compared to the negative control while it significantly 
Table 1: Antidiarrheal effects of C. abyssinica extract and solvent fractions.

\begin{tabular}{|c|c|c|c|c|c|}
\hline Treatments given & & $\begin{array}{l}\text { Onset of wet stool appearance } \\
(\mathrm{min})\end{array}$ & $\begin{array}{l}\text { Number of wet } \\
\text { stools }\end{array}$ & $\begin{array}{c}\text { Number of total } \\
\text { stools }\end{array}$ & $\begin{array}{l}\% \text { reduction of wet } \\
\text { stools }\end{array}$ \\
\hline Negative control & & $72.00 \pm 7.86$ & $10.83 \pm 0.79$ & $14.33 \pm 0.99$ & - \\
\hline Extract $(\mathrm{mg} / \mathrm{kg})$ & $\begin{array}{l}100 \\
200 \\
400\end{array}$ & $\begin{array}{c}131.67 \pm 12.65^{\mathrm{e} *} \\
147.17 \pm 18.05^{\mathrm{a} *} \\
158.00 \pm 14.64^{\mathrm{a} * *}\end{array}$ & $\begin{array}{l}7.33 \pm 1.26^{\mathrm{e} * *} \\
5.00 \pm 0.86^{\mathrm{a} * * *} \\
3.50 \pm 0.22^{\mathrm{a} * * *}\end{array}$ & $\begin{array}{c}10.50 \pm 1.46^{\mathrm{d} * \mathrm{e} * *} \\
7.50 \pm 1.26^{\mathrm{a} * * *} \\
5.50 \pm 0.43^{\mathrm{a} * * * \mathrm{~b} *}\end{array}$ & $\begin{array}{l}32.32 \\
53.83 \\
67.68\end{array}$ \\
\hline Solvent fractions $(\mathrm{mg} / \mathrm{kg})$ & $\begin{array}{c}\text { CF100 } \\
\text { CF200 } \\
\text { CF400 } \\
n \text {-BF100 } \\
n \text {-BF200 } \\
n \text {-BF400 } \\
\text { AF100 } \\
\text { AF200 } \\
\text { AF400 }\end{array}$ & $\begin{array}{c}88.50 \pm 7.20^{\mathrm{d} * \mathrm{e}_{* * *}} \\
106.17 \pm 6.72^{\mathrm{e} * *} \\
180.00 \pm 15.30^{\mathrm{a}_{* * *}} \\
83.33 \pm 12.46^{\mathrm{d}_{*} \mathrm{e}_{* * *}} \\
87.50 \pm 11.70^{\mathrm{d}_{*} \mathrm{e}_{* * *}} \\
119.33 \pm 23.02^{\mathrm{e} * *} \\
91.00 \pm 11.28^{\mathrm{e} * * *} \\
102.00 \pm 13.02^{\mathrm{e} * * *} \\
120.50 \pm 17.87^{\mathrm{e} * *}\end{array}$ & $\begin{array}{c}7.83 \pm 0.70^{\mathrm{d} * \mathrm{e} * *} \\
6.50 \pm 0.56^{\mathrm{a} * \mathrm{e} *} \\
4.00 \pm 0.45^{\mathrm{a} * * *} \\
7.17 \pm 1.20^{\mathrm{e} * *} \\
6.33 \pm 0.92^{\mathrm{a} *} \\
4.17 \pm 0.54^{\mathrm{a} * * *} \\
5.67 \pm 1.36^{\mathrm{a} * *} \\
4.50 \pm 0.56^{\mathrm{a} * * *} \\
3.67 \pm 0.76^{\mathrm{a} * * *} \\
\end{array}$ & $\begin{array}{c}10.50 \pm 0.96^{\mathrm{d} * \mathrm{e} * *} \\
9.67 \pm 0.76^{\mathrm{a} * \mathrm{e} *} \\
5.83 \pm 0.60^{\mathrm{a} * * * \mathrm{~b} *} \\
9.67 \pm 0.88^{\mathrm{a} * \mathrm{e} *} \\
8.67 \pm 1.02^{\mathrm{a} * *} \\
7.17 \pm 0.70^{\mathrm{a} * * *} \\
8.17 \pm 1.20^{\mathrm{a} * *} \\
7.00 \pm 0.37^{\mathrm{a} * * *} \\
6.00 \pm 0.68^{\mathrm{a} * * *}\end{array}$ & $\begin{array}{l}27.70 \\
39.98 \\
63.07 \\
33.80 \\
41.55 \\
61.50 \\
47.65 \\
58.45 \\
66.11 \\
\end{array}$ \\
\hline Positive control & & $199.00 \pm 8.77^{\mathrm{a} * * * \mathrm{~b} *}$ & $2.33 \pm 0.62^{\mathrm{a} * * * \mathrm{~b} * *}$ & $4.67 \pm 0.72^{\mathrm{a} * * * \mathrm{~b} * *}$ & 80.95 \\
\hline
\end{tabular}

Values are expressed as mean \pm SEM $(n=6)$; analysis was performed using one-way ANOVA followed by Tukey's post hoc test; ${ }^{2}$ compared to negative control, ${ }^{\text {b }}$ compared to $100 \mathrm{mg} / \mathrm{kg}$ crude extract, ${ }^{c}$ compared to $200 \mathrm{mg} / \mathrm{kg}$ crude extract, ${ }^{\mathrm{d}}$ compared to $400 \mathrm{mg} / \mathrm{kg}$ crude extract, ${ }^{\mathrm{e}}$ compared to positive control. ${ }^{*} p<0.05 ;{ }^{* *} p<0.01 ;{ }^{* * *} p<0.001$. $\mathrm{CF}=$ Chloroform fraction; $n-\mathrm{BF}=n$-butanol fraction; $\mathrm{AF}$, aqueous fraction.

decreased both volume $(p<0.01)$ and weight $(p<0.05)$ of intestinal content at a dose of $400 \mathrm{mg} / \mathrm{kg}$ (Table 2).

The chloroform and $n$-butanol fractions reduced VSIC significantly at doses of $200 \mathrm{mg} / \mathrm{kg}(p<0.01)$ and $400 \mathrm{mg} / \mathrm{kg}$ $(p<0.001)$. Maximal percentage reduction of VSIC was observed at $400 \mathrm{mg} / \mathrm{kg}$, being $47.68 \%$ and $51.73 \%$ for chloroform and $n$-butanol fractions, respectively. Aqueous fraction showed a significant percentage reduction in VSIC at all test doses with a maximal percentage reduction $(43.24 \%)$ at $400 \mathrm{mg} / \mathrm{kg}$.

The $n$-butanol fraction showed a significant reduction of WSIC $(p<0.05)$ at doses of 200 and $400 \mathrm{mg} / \mathrm{kg}$. The hydromethanolic root extract of C. abyssinica, chloroform, and aqueous fractions conferred a significant reduction $(p<0.05)$ in the WSIC at a dose of $400 \mathrm{mg} / \mathrm{kg}$.

3.4. Effect on Intestinal Transit. The hydromethanolic root extract of C. abyssinica significantly inhibited the intestinal transit of charcoal meal at $400 \mathrm{mg} / \mathrm{kg}$. At $100 \mathrm{mg} / \mathrm{kg}$ and $200 \mathrm{mg} / \mathrm{kg}$, it was devoid of a significant effect on the motility the intestine. As shown in Table 3, the percentage reduction of gastrointestinal transit of charcoal was $17.22 \%, 24.24 \%$, and $52.41 \%$ at doses of $100 \mathrm{mg} / \mathrm{kg}, 200 \mathrm{mg} / \mathrm{kg}$, and $400 \mathrm{mg} /$ $\mathrm{kg}$, respectively.

Chloroform and $n$-butanol fractions significantly reduced the distance moved by charcoal at doses of $200 \mathrm{mg} / \mathrm{kg}$ and $400 \mathrm{mg} / \mathrm{kg}$, whereas aqueous fraction showed a significant effect at all test doses. The data revealed that the hydromethanolic root extract and all fractions showed dose-dependent percentage inhibition of the intestinal transit of charcoal meal.

3.5. The In Vivo Antidiarrheal Index. Antidiarrheal index was calculated to determine the relative effect of extract and fractions (Table 4). The highest ADI was obtained at a dose of $400 \mathrm{mg} / \mathrm{kg}$ of the extract $(75.15 \%)$ and chloroform fraction (75.19\%). Both the extract and solvent fractions showed increment in the in vivo ADI value in a dose-dependent manner.

\section{Discussion}

The present study aimed at providing the pharmacological basis for the medicinal use of the root extract of C. abyssinica in diarrhea using mice. In many areas of Ethiopia, C. abyssinica is used for the treatment of different health problems including diarrhea without scientific substantiation of its safety and efficacy. This study was conducted to evaluate the claimed antidiarrheal effect of C. abyssinica using antidiarrheal activity test models in mice. In the study, the castor oil induced diarrheal model was done in order to test as to whether the extracts of C. abyssinica have an antidiarrheal activity or not. Then, other models (antipropulsive and antienteropooling) were used in an attempt to propose some of the possible mechanisms (decrease in GI transit and antisecretory activities) by which they exhibited antidiarrheal activity.

Generally, high extraction yield can be achieved by using hydroalcoholic solvent mixtures due to their expanded polarity index [22]. Since methanol is highly soluble in water, a wide range of compounds with different polarities could be extracted (nonpolar to polar) using a hydromethanolic solvent mixture. Hence, hydromethanol was used as a solvent in the present study for the initial extraction of the roots of C. abyssinica. In addition, the hydromethanolic root extract was suspended in distilled water for fractionation with solvents of increasing polarity to investigate the partitioning property of antidiarrheal constituents of the plant.

The acute oral toxicity profile of the hydromethanolic root extract of C. abyssinica was determined based on OECD guidelines 2008:425 [19]. At a dose of $2000 \mathrm{mg} / \mathrm{kg}$, mortality and delayed toxicity were not observed in the 14 days after the treatment period. In this study, the $\mathrm{LD}_{50}$ value of the hydromethanolic root extract of C. abyssinica was found to 
TAвLE 2: Antienteropooling effects of C. abyssinica extract and solvent fractions.

\begin{tabular}{|c|c|c|c|c|c|}
\hline Treatment given & & VSIC (ml) & $\begin{array}{c}\% \text { inhibition } \\
\text { in volume }\end{array}$ & WSIC (g) & $\begin{array}{c}\% \text { inhibition } \\
\text { in weight }\end{array}$ \\
\hline Negative control & & $0.86 \pm 0.03$ & - & $0.91 \pm 0.03$ & - \\
\hline \multirow{3}{*}{ Extract $(\mathrm{mg} / \mathrm{kg})$} & 100 & $0.74 \pm 0.03^{\mathrm{e} * * *}$ & 14.48 & $0.80 \pm 0.03^{\mathrm{e} * *}$ & 11.56 \\
\hline & 200 & $0.62 \pm 0.03^{\mathrm{e}_{* *}}$ & 28.18 & $0.73 \pm 0.02^{\mathrm{e}_{*}}$ & 19.44 \\
\hline & 400 & $0.47 \pm 0.02^{\mathrm{a} * *}$ & 45.74 & $0.50 \pm 0.02^{\mathrm{a} *}$ & 45.42 \\
\hline \multirow{9}{*}{ Solvent fractions $(\mathrm{mg} / \mathrm{kg})$} & CF 100 & $0.68 \pm 0.05^{\mathrm{e} * * *}$ & 10.23 & $0.78 \pm 0.09^{\mathrm{e}^{* *}}$ & 25.50 \\
\hline & CF 200 & $0.47 \pm 0.33^{\mathrm{a} * *}$ & 25.09 & $0.65 \pm 0.05$ & 48.44 \\
\hline & CF 400 & $0.39 \pm 0.04^{\mathrm{a} * * * \mathrm{~b} *}$ & 47.68 & $0.45 \pm 0.121^{\mathrm{a} *}$ & 56.88 \\
\hline & $n$-BF 100 & $0.67 \pm 0.06^{\mathrm{e} * * *}$ & 20.65 & $0.69 \pm 0.13$ & 26.60 \\
\hline & $n$-BF 200 & $0.43 \pm 0.03^{\mathrm{a} * * *} \mathrm{~b}_{*}$ & 50.39 & $0.49 \pm 0.03^{\mathrm{a} *}$ & 45.87 \\
\hline & $n$-BF 400 & $0.35 \pm 0.08^{\mathrm{a} * * * \mathrm{~b} * *}$ & 51.73 & $0.42 \pm 0.09^{\mathrm{a} * *}$ & 61.47 \\
\hline & AF 100 & $0.55 \pm 0.08^{\mathrm{a} * \mathrm{e} *}$ & 33.20 & $0.58 \pm 0.12$ & 39.45 \\
\hline & AF 200 & $0.50 \pm 0.12^{\mathrm{a} * *}$ & 41.70 & $0.51 \pm 0.10$ & 44.40 \\
\hline & AF 400 & $0.33 \pm 0.10^{\mathrm{a} * * * \mathrm{~b} * *}$ & 43.24 & $0.49 \pm 0.09^{\mathrm{a} *}$ & 63.86 \\
\hline Positive control & & $0.20 \pm 0.07^{\mathrm{a} * * * \mathrm{~b} * * *}$ & 65.25 & $0.30 \pm 0.11^{\mathrm{a} * * * \mathrm{~b} * *}$ & 77.98 \\
\hline
\end{tabular}

Values are expressed as mean \pm SEM $(n=6)$; analysis was performed using one-way ANOVA followed by Tukey's post hoc test; ${ }^{a}$ compared to negative control, ${ }^{\text {b }}$ compared to $100 \mathrm{mg} / \mathrm{kg}$ crude extract, ${ }^{c}$ compared to $200 \mathrm{mg} / \mathrm{kg}$ crude extract, ${ }^{\mathrm{d}}$ compared to $400 \mathrm{mg} / \mathrm{kg}$ crude extract, ${ }^{\mathrm{e}}$ compared to positive control. ${ }^{*} p<0.05 ;{ }^{* *} p<0.01 ;{ }^{* * *} p<0.001$. CF = chloroform fraction; $n-\mathrm{BF}=n$-butanol fraction; $\mathrm{AF}=$ aqueous fraction; $\mathrm{VSIC}=$ volume of small intestinal content; WSIC = weight of small intestinal content.

TABle 3: The effect of root extract and fractions of C. abyssinica on intestinal transit in mice.

\begin{tabular}{|c|c|c|c|c|c|}
\hline Treatment given & & $\begin{array}{c}\text { Length of the } \\
\text { small intestine }(\mathrm{cm})\end{array}$ & $\begin{array}{l}\text { Distance moved by } \\
\text { charcoal meal }(\mathrm{cm})\end{array}$ & Peristaltic index & $\%$ inhibition \\
\hline Negative control & & $60.00 \pm 1.53$ & $49.17 \pm 1.96$ & $81.90 \pm 2.09$ & - \\
\hline \multirow{3}{*}{ Extract $(\mathrm{mg} / \mathrm{kg})$} & 100 & $61.50 \pm 1.57$ & $41.50 \pm 2.46^{\mathrm{d} * * \mathrm{e} * * *}$ & $67.80 \pm 4.88^{\mathrm{d} * \mathrm{e} * *}$ & 17.22 \\
\hline & 200 & $60.83 \pm 1.45$ & $37.67 \pm 3.92^{\mathrm{d} * \mathrm{e} * *}$ & $62.05 \pm 6.77^{\mathrm{e} *}$ & 24.24 \\
\hline & 400 & $61.17 \pm 1.49$ & $23.67 \pm 1.38^{\mathrm{a} * * * \mathrm{~b} * *}$ & $38.98 \pm 2.97^{\mathrm{a} * * * \mathrm{~b} *}$ & 52.41 \\
\hline \multirow{9}{*}{ Solvent fractions $(\mathrm{mg} / \mathrm{kg})$} & CF 100 & $54.33 \pm 2.01$ & $35.83 \pm 1.99^{\mathrm{e} *}$ & $66.55 \pm 4.91^{\mathrm{d} * \mathrm{e}_{* *}}$ & 18.74 \\
\hline & CF 200 & $51.17 \pm 1.01$ & $25.33 \pm 4.10^{\mathrm{a} * * * \mathrm{~b} *}$ & $49.88 \pm 9.86^{\mathrm{a} * *}$ & 39.10 \\
\hline & CF 400 & $60.33 \pm 1.41$ & $27.00 \pm 2.98^{\mathrm{a} * * * \mathrm{~b} *}$ & $45.08 \pm 5.49^{\mathrm{a} * * *}$ & 44.96 \\
\hline & $n$-BF 100 & $57.83 \pm 1.82$ & $36.00 \pm 3.09^{\mathrm{e}_{*}}$ & $61.98 \pm 4.39^{\mathrm{e}_{*}}$ & 24.32 \\
\hline & $n$-BF 200 & $57.00 \pm 2.44$ & $31.00 \pm 2.37^{\mathrm{a} * *}$ & $54.67 \pm 4.03^{\mathrm{a} *}$ & 33.25 \\
\hline & $n$-BF 400 & $58.67 \pm 1.33$ & $30.67 \pm 3.02^{\mathrm{a} * *}$ & $52.35 \pm 5.02^{\mathrm{a} * *}$ & 36.08 \\
\hline & AF 100 & $54.00 \pm 2.31$ & $30.33 \pm 3.60^{\mathrm{a} * *}$ & $56.67 \pm 6.67^{\mathrm{a} *}$ & 30.81 \\
\hline & AF 200 & $55.83 \pm 2.27$ & $29.50 \pm 2.75^{\mathrm{a} * *}$ & $52.82 \pm 4.25^{\mathrm{a} *}$ & 35.52 \\
\hline & AF 400 & $53.67 \pm 2.75$ & $23.17 \pm 1.05^{\mathrm{a} * * * \mathrm{~b} * *}$ & $43.50 \pm 2.09^{\mathrm{a} * * *}$ & 46.89 \\
\hline Positive control & & $60.83 \pm 1.35$ & $21.33 \pm 1.67^{\mathrm{a} * * * \mathrm{~b}_{* * *}}$ & $35.07 \pm 2.52^{\mathrm{a} * * * \mathrm{~b} * *}$ & 57.19 \\
\hline
\end{tabular}

$\mathrm{CF}=$ chloroform fraction; $n-\mathrm{BF}=n$-butanol fraction; $\mathrm{AF}=$ aqueous fraction. Values are expressed as mean \pm standard error of mean $(n=6)$; analysis was performed using one-way ANOVA followed by Tukey's post hoc test. ${ }^{a}$ compared to negative control, b ${ }^{b}$ compared to $100 \mathrm{mg} / \mathrm{kg}$ crude extract, ${ }^{\mathrm{c}} \mathrm{compared}$ to $200 \mathrm{mg} / \mathrm{kg}$ crude extract, ${ }^{\mathrm{d}}$ compared to $400 \mathrm{mg} / \mathrm{kg}$ crude extract, ${ }^{\mathrm{e}}$ compared to positive control. ${ }^{*} p<0.05 ;{ }^{* *} p<0.01 ;{ }^{* * *} p<0.001$.

be $>2000 \mathrm{mg} / \mathrm{kg}$. This indicates that the extract is better tolerated and safe upon oral administration. Based on the safety data of this extract, acute oral toxicity tests were not done on solvent fractions.

Castor oil was used in this study to induce diarrhea as it is a known fact that the ricinoleic acid, which is the active component of castor oil, is liberated by the action of lipases on castor oil. The ricinoleic acid produces irritation and inflammatory actions on intestinal mucosa leading to the release of prostaglandins (such as PG-E2) and hence induce diarrhea [27].

Castor oil induced diarrheal model was designed to assess the overall antidiarrheal activities of extract and fractions. The onset of defecation and the numbers of wet and total stools were determined as the main parameters. Hydromethanolic root extract (at the middle and higher doses) of C. abyssinica significantly delayed the onset of diarrhea, the numbers of wet and total stools. This was in line with other reports of different species of plants in which extracts had shown to exert an antidiarrheal effect at higher doses [28].

Determination of the consistency of stools is given a greater emphasis than the frequency in the evaluation of the antidiarrheal activity of test substances. Hence, the percentage reduction of wet stools has been determined. Diarrhea is also presented with an increase in the number of wet stools [22]. In this model, the hydromethanolic extract showed a dose-dependent inhibition of wet stools indicating the antidiarrheal activity of the extract.

Chloroform, $n$-butanol, and aqueous fractions (at the middle and higher doses) produced significant effects in 
TABLe 4: In vivo antidiarrheal indices of root extract and fractions of $C$. abyssinica.

\begin{tabular}{|c|c|c|c|c|c|}
\hline Treatments given & & Dfreq (\%) & Gmeq (\%) & Pfreq (\%) & ADI (\%) \\
\hline \multirow{3}{*}{ Extract $(\mathrm{mg} / \mathrm{kg})$} & 100 & 82.88 & 17.22 & 32.32 & 35.86 \\
\hline & 200 & 104.40 & 24.24 & 53.83 & 51.45 \\
\hline & 400 & 119.44 & 52.41 & 67.80 & 75.15 \\
\hline \multirow{9}{*}{ Solvent fractions $(\mathrm{mg} / \mathrm{kg})$} & CF 100 & 22.92 & 18.74 & 27.70 & 22.83 \\
\hline & CF 200 & 47.46 & 39.10 & 39.98 & 42.02 \\
\hline & CF 400 & 150.00 & 44.96 & 63.02 & 75.19 \\
\hline & $n$-BF 100 & 15.74 & 23.32 & 33.80 & 23.15 \\
\hline & $n$-BF 200 & 21.53 & 33.25 & 41.55 & 30.98 \\
\hline & $n$-BF 400 & 65.74 & 36.08 & 61.50 & 52.64 \\
\hline & AF 100 & 26.39 & 30.81 & 47.65 & 33.84 \\
\hline & AF 200 & 41.67 & 35.52 & 58.45 & 44.23 \\
\hline & AF 400 & 67.36 & 46.89 & 66.11 & 59.33 \\
\hline Positive control & & 176.39 & 57.19 & 80.95 & 93.47 \\
\hline
\end{tabular}

$\mathrm{CF}=$ chloroform fraction; $n-\mathrm{BF}=n$-butanol fraction; $\mathrm{AF}=$ aqueous fraction; Dfreq $=$ the delay in defecation time as a percentage of negative control; Gmeq = the gut meal travel reduction as a percentage of negative control; Pfreq= the reduction in purging frequency in the number of wet stools as a percentage of negative control; ADI = antidiarrheal index.

reducing wet stools in this model. In addition, the aqueous fraction significantly decreased the number of wet feces at $100 \mathrm{mg} / \mathrm{kg}$. Chloroform fraction significantly delayed the initiation of diarrhea at $400 \mathrm{mg} / \mathrm{kg}$, whereas $n$-butanol and aqueous fractions were devoid of any significant delay in the onset of diarrhea at all test doses. This study was in agreement with other studies where the aqueous fraction was not effective to delay the onset of diarrhea [22]. On the other hand, the aqueous fraction significantly reduced the number of wet and total stools at all test doses. This could be due to the partitioning of antidiarrheal constituents in this fraction. According to previous phytochemical studies, the hydromethanolic root extract of $C$. abyssinica was found to have different secondary metabolites such as tannins, flavonoids, alkaloids, saponins, phenols, terpenoids, anthraquinones, and glycosides $[12,29]$. Hence, it is plausible to assume that more polar secondary metabolites could be responsible for the inhibition of the diarrheal parameters (onset of diarrhea, number of wet stools, and the total number of stools) measured [30, 31].

The enteropooling model was designed to assess the antisecretory effect of hydromethanolic root extract and fractions of $C$. abyssinica. In this model, the hydromethanolic extract showed a significant reduction in both AVIC and AWIC at the highest doses $(400 \mathrm{mg} / \mathrm{kg}$ ) as compared to a negative control. Aqueous fraction showed a significant percentage reduction in VSIC at all test doses with a maximal percentage reduction $(43.24 \%)$ at $400 \mathrm{mg} / \mathrm{kg}$. The pronounced inhibition of castor oil induced intestinal fluid accumulation in the aqueous fraction could possibly be related to the presence of flavonoids and tannins [32]. The aforementioned secondary metabolites were screened from this plant as reported in previous studies [12, 29].

Nonsteroidal anti-inflammatory drugs could inhibit castor oil induced diarrhea [22]. Similarly, the extract of C. abysinica showed anti-inflammatory activity in a previous study [33].

In the intestinal transit model, hydromethanolic root extract and fractions of $C$. abyssinica reduced the transit of charcoal meal through the intestinal tract which indicates that the root extract and fractions are capable of inhibiting the frequency of fecal output. Suppression of the propulsion of activated charcoal is due to the inhibition of peristaltic movements of the GIT system and muscle relaxant effect of extract and solvent fractions [33]. The reduction in gastrointestinal motility increases the time of stay of gastrointestinal contents in the intestine, and this may promote intestinal water and electrolyte absorption. The findings of this study are in agreement with the previous antidiarrheal study on Justicia schimperiana, which displayed antimotility activity [6].

Generally, ADI is a measure of the effectiveness of an extract in treating diarrhea [22]. The higher the ADI value, the greater is the effectiveness in the treatment of diarrhea. C. abysinica root extract produced a dose-dependent antidiarrheal index. The highest test dose of the extract with the highest ADI value is endowed with the best antidiarrheal activity compared to the other doses.

According to previous studies, the plant extract has antimicrobial activities against such pathogenic organisms as $S$. typhi, E. coli, S. dysenteriae, K. pneumonia, and C. albicans $[34,35]$. Therefore, in addition to its antimotility and antisecretory activities observed in this study, C. abyssinica can be effective in treating diarrhea caused by infection.

\section{Conclusion}

The results of the present study revealed that the root extract and aqueous fraction of $C$. abyssinica are endowed with promising antidiarrheal activity. These findings provide scientific support for the folkloric repute of $C$. abyssinica roots as treatment of diarrhea.

\section{Data Availability}

All the materials and data of our study are included in the article. 


\section{Conflicts of Interest}

The authors declare that they have no conflicts of interest.

\section{Authors' Contributions}

Dessie Zayede (MSc) conceived the study, designed and conducted all laboratory experiments, and analyzed and interpreted experimental results. Wubayehu Kahaliw (PhD) and Tafere Mulaw (MSc) participated in the proposal development, study design, and analysis of results. All authors read and approved the final manuscript.

\section{Acknowledgments}

The authors acknowledge the University of Gondar for allowing the laboratory setup to conduct this research.

\section{References}

[1] S. S. Mehesare, S. P. Waghmare, M. G. Thorat et al., "Evaluation of antidiarrheal activity of polyherbal preparation," Journal of Pharmacognosy and Phytochemistry, vol. 6, no. 6, pp. 723-725, 2017.

[2] M. Mokomane, I. Kasvosve, E. de Melo, J. M. Pernica, and D. M. Goldfarb, "The global problem of childhood diarrheal diseases: emerging strategies in prevention and management," Therapeutic Advances in Infectious Disease, vol. 5, no. 1, pp. 29-43, 2018.

[3] J. R. Thiagarajah, D. S. Kamin, S. Acra et al., "Advances in evaluation of chronic diarrhea in infants," Gastroenterology, vol. 154, no. 8, pp. 2045-2059.e6, 2018.

[4] A. Alebel, C. Tesema, B. Temesgen, A. Gebrie, P. Petrucka, and G. Kibret, "Prevalence and determinants of diarrhea among under-five children in Ethiopia: a systematic review and metaanalysis," PLoS One, vol. 13, no. 6, Article ID e0199684, 2018.

[5] K. D. Kassaye, A. Amberbir, B. Getachew, and Y. Mussema, "A historical overview of traditional medicine practices and policy in Ethiopia," Ethiopian Journal of Health Development, vol. 20, no. 2, pp. 127-134, 2007.

[6] B. Mekonnen, A. B. Asrie, and Z. B. Wubneh, "Antidiarrheal activity of $80 \%$ methanolic leaf extract of Justicia schimperiana," Evidence-Based Complementary and Alternative Medicine, vol. 2018, Article ID 3037120, 10 pages, 2018.

[7] B. Woldeab, R. Regassa, T. Alemu, and M. Megersa, "Medicinal plants used for treatment of diarrheal related diseases in Ethiopia," Evidence-Based Complementary and Alternative Medicine, vol. 2018, Article ID 4630371, 20 pages, 2018.

[8] F. Mesfin, T. Seta, and A. Assefa, "An ethnobotanical study of medicinal plants in Amaro Woreda, Ethiopia," Ethnobotany Research and Applications, vol. 12, pp. 341-354, 2014.

[9] T. Teklehaymanot and M. Giday, "Ethnobotanical study of medicinal plants used by people in Zegie peninsula, northwestern Ethiopia," Journal of Ethnobiology and Ethnomedicine, vol. 3, no. 1, p. 12, 2007.

[10] L. J. McGaw, A. K. Jäger, and J. van Staden, "Antibacterial, anthelmintic and anti-amoebic activity in South African medicinal plants," Journal of Ethnopharmacology, vol. 72, no. 1-2, pp. 247-263, 2000.

[11] G. Chekole, Z. Asfaw, and E. Kelbessa, "Ethnobotanical study of medicinal plants in the environs of tara-gedam and amba remnant forests of Libo Kemkem district, northwest
Ethiopia," Journal of Ethnobiology and Ethnomedicine, vol. 11, no. 1, p. 4, 2015.

[12] E. A. Palombo, "Phytochemicals from traditional medicinal plants used in the treatment of diarrhea: modes of action and effects on intestinal function," Phytotherapy Research, vol. 20, no. 9, pp. 717-724, 2006.

[13] S. R. Bijekar and M. C. Gayatri, "Ethanomedicinal properties of Euphorbiaceae family-a comprehensive review," International Journal of Phytmedicine, vol. 6, no. 2, pp. 144-156, 2014.

[14] A. Enyew, Z. Asfaw, E. Kelbessa, and R. Nagappan, "Ethnobotanical study of traditional medicinal plants in and around fiche district, Central Ethiopia," Current Research Journal of Biological Sciences, vol. 6, no. 4, pp. 154-167, 2014.

[15] Y. Limenih, S. Umer, and M. Wolde-Mariam, "Ethnobotanical study on traditional medicinal plants in Dega Damot woreda, Amhara region, north Ethiopia," International Journal of Research in Pharmacy and Chemistry, vol. 5, no. 2, pp. 258-273, 2015.

[16] M. Kuma and S. Shibru, "Floristic composition, vegetation structure, and regeneration status of woody plant species of oda forest of humbo carbon project, wolaita, Ethiopia," Journal of Botany, vol. 2015, Article ID 963816, 9 pages, 2015.

[17] E. Lulekal, J. Rondevaldova, E. Bernaskova et al., "Antimicrobial activity of traditional medicinal plants from Ankober district, north Shewa Zone, Amhara region, Ethiopia," Pharmaceutical Biology, vol. 52, no. 5, pp. 614-620, 2014.

[18] E. Lulekal, Z. Asfaw, E. Kelbessa, and P. Van Damme, "Ethnoveterinary plants of Ankober district, north Shewa Zone, Amhara region, Ethiopia," Journal of Ethnobiology and Ethnomedicine, vol. 10, no. 1, p. 21, 2014.

[19] OECD, Guidelines for Testing of Chemicals: Guideline 425: Acute Oral Toxicity, OECD, Paris, France, 2008, http://www. oecd-ilibrary.org/environment/oecdguidelines-for-the-testingofchemicals-section-4-health-effe.

[20] H. G. Vogel, Drug Discovery and Evaluation: Pharmacological Assays, Springer-Verlag, New York, NY, USA, 3rd edition, 2008.

[21] G. Ayal, A. Belay, and W. Kahaliw, "Evaluation of wound healing and antiinflammatory activity of the leaves of Calpurnia aurea (ait.) Benth (fabaceae) in mice," Wound Medicine, vol. 25, no. 1, Article ID 100151, 2019.

[22] M. Sisay, E. Engidawork, and W. Shibeshi, "Evaluation of the antidiarrheal activity of the leaf extracts of Myrtus communis linn (myrtaceae) in mice model," BMC Complementary and Alternative Medicine, vol. 17, no. 1, p. 103, 2017.

[23] M. Mahalakshmi, M. Parimala, and F. G. Shoba, "Evaluation of antidiarrheal potential of methanol extract of Ficus bengalensis linn. leaf and Mangifera indica linn. stem bark and root bark," International Journal of Pharmacognosy and Phytochemical Research, vol. 6, no. 3, pp. 454-458, 2014.

[24] A. Robert, J. E. Nezamis, C. Lancaster, A. J. Hanchar, and M. S. Klepper, "Enteropooling assay: a test for diarrhea produced by prostaglandins," Prostaglandins, vol. 11, no. 5, pp. 809-828, 1976.

[25] A. B. Asrie, M. Abdelwuhab, Z. Shewamene, D. A. Gelayee, G. M. Adinew, and E. Birru, "Antidiarrheal activity of methanolic extract of the root bark of Cordia africana," Journal of Experimental Pharmacology, vol. 8, pp. 53-59, 2016.

[26] G. Akuodor, I. Muazzam, M. Usman-Idris et al., "Evaluation of the antidiarrheal activity of methanol leaf extract of Bombax buonopozense in rats," Ibnosina Journal of Medicine and Biomedical Sciences, vol. 3, no. 1, pp. 15-20, 2011.

[27] S. Tunaru, T. F. Althoff, R. M. Nusing, M. Diener, and S. Offermanns, "Castor oil induces laxation and uterus 
contraction via ricinoleic acid activating prostaglandin EP3 receptors," Proceedings of the National Academy of Sciences, vol. 109, no. 23, pp. 9179-9184, 2012.

[28] W. C. Evans, D. Evans, and G. E. Trease, Trease and Evans Pharmacognosy, Saunders/Elsevier, New York, NY, USA, 16th edition, 2009.

[29] A. Wadood, M. Ghufran, S. B. Jamal, M. Naeem, A. Khan, and R. Ghaffar, "Phytochemical analysis of medicinal plants occurring in local area of Mardan," Biochemistry \& Analytical Biochemistry, vol. 2, no. 4, p. 144, 2013.

[30] R. P. Poli, R. J. Venkateshwar, and K. R. Sambasiva, "Pharmacological evaluation of antidiarrheal activity of Momordica cymbalaria," Indian Journal of Pharmaceutical Science \& Research, vol. 5, pp. 136-138, 2015.

[31] S. K. Panda, D. Das, and N. K. Tripthathy, "Antidiarrheal activity of various root extracts of Gmelina arborea roxb. In experimentally induced diarrhea in mice," World Journal of Pharmacy and Pharmaceutical Sciences, vol. 4, pp. 912-919, 2015.

[32] J. Galvez, A. Zarzuelo, M. E. Crespo et al., "Antidiarrhoeic activities of Scleroarya birrea bark extracts and its tannin constituent in rat," Phytotherapy Research, vol. 5, no. 6, pp. 276-278, 1991.

[33] S. C. Koech, A. V. Sindani, J. B. Maoga, R. O. Ouko, N. M. Njagi, and M. P. Ngugi, "Anti-pyretic potential of dichloromethanolic root extract of Clutia abyssinica in wistar albino rats," Medicinal \& Aromatic Plants, vol. 6, no. 1, p. 281, 2017.

[34] D. Derebe, M. Abdulwuhab, M. Wubetu, and F. Mohammed, "Investigation of the antidiarrheal and antimicrobial activities of $80 \%$ methanolic leaf extract of discopodium penninervum (hochst.)," Evidence-Based Complementary and Alternative Medicine, vol. 2018, Article ID 1360486, 7 pages, 2018.

[35] O. H. Nyang'au, J. Maingi, and A. Kebira, "The efficacy of some medicinal plants used locally within transmara west, narok county, Kenya against selected enterobacteria and Candida," IOSR Journal of Pharmacy and Biological Sciences, vol. 12, no. 1, pp. 115-122, 2017. 


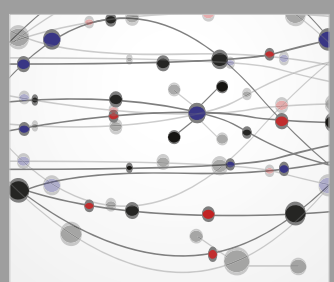

The Scientific World Journal
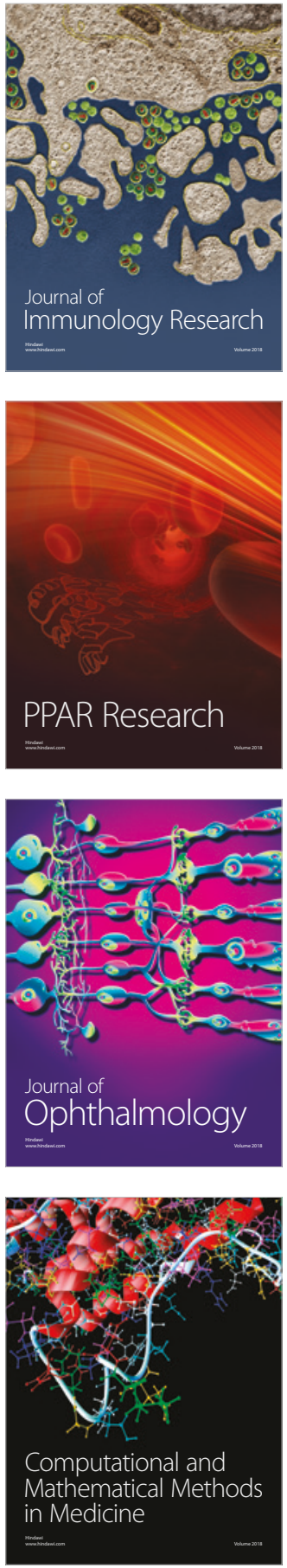

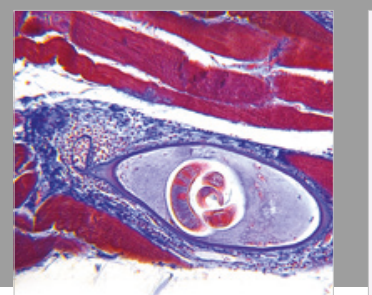

Gastroenterology Research and Practice

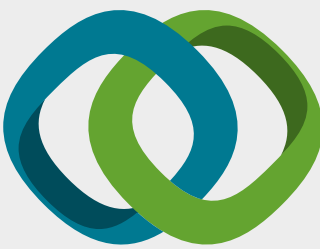

\section{Hindawi}

Submit your manuscripts at

www.hindawi.com
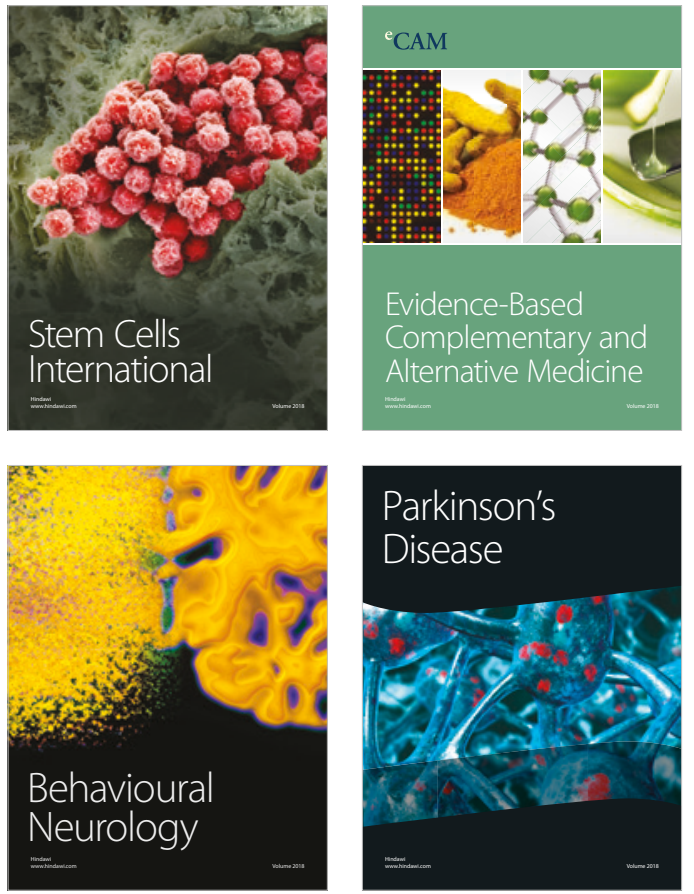

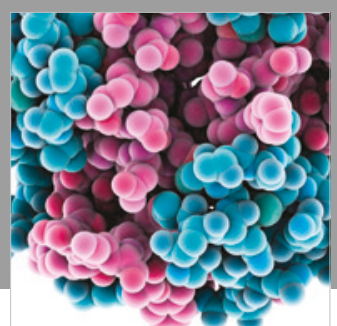

ournal of

Diabetes Research

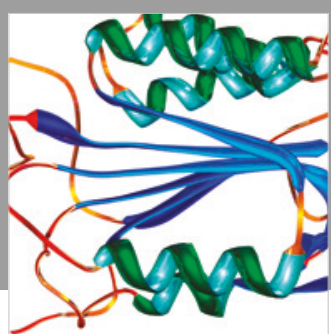

Disease Markers
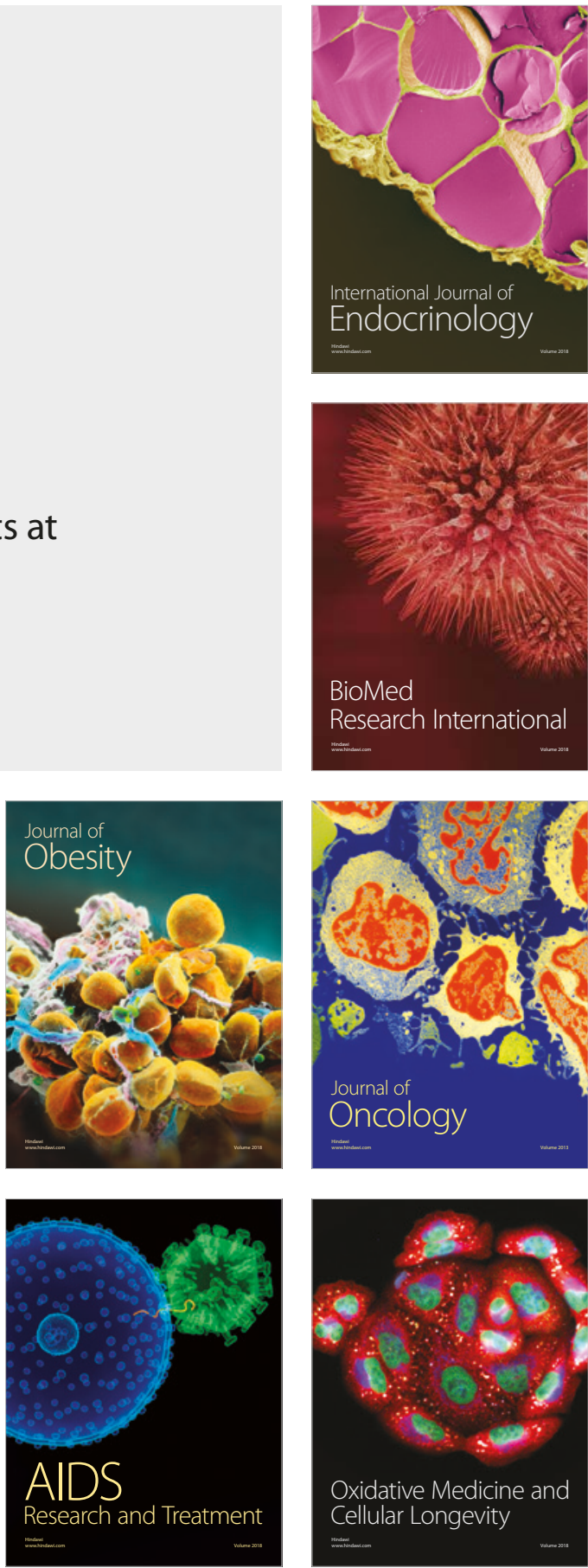